\title{
Recollections of the New South Wales Working Party
}

\author{
Russell Doust
}

When I became State Librarian of New South Wales in early 1973, I 'inherited' from my predecessor, Gordon Richardson, the chairmanship of the $A D B^{\prime}$ s NSW Working Party. This was not prescribed in any book of rules (unlike, for instance, membership of the NSW Geographic Names Board or the NSW Council of the National Trust of Australia, both of which named the state librarian or his nominee in the enabling legislation). Richardson had been chair of the working party almost from the beginning, as far as I can infer from the list of members in Volume 7, taking over after a year or two from the first chairman, Bede Nairn.

Neither Richardson nor I were professional historians, although Richardson had written a well-regarded MA thesis (University of Sydney) on the records of the NSW colonial secretary, while I had (in about 1969) submitted my thesis for the degree of master of librarianship to the University of New South Wales on 'The Administration of Official Archives in New South Wales 1870-1960'. I do not know where the working party first met, but I suspect that it had always been in the State library (formerly the Public Library of New South Wales). Apart from any other considerations, this might well have been a reason for the choice of Richardson as chairman in place of Nairn. Perhaps the only comment I should make about my own chairmanship of the working party is that I seemed to be accepted for what I was-landlord, whose institution provided space and tea and coffee for meetings. My knowledge of Australian history was not great because it was not taught in my University of Sydney undergraduate days, but I did know about controlling and guiding a committee and, for the whole of my chairmanship, I was guided by Chris Cunneen, who was both a member of the working party and the close link with the $A D B$ office in Canberra.

I never proposed a possible 'biographee' to the working party, nor did I ever contribute an entry. Richardson, on the other hand, wrote six entries for the $A D B$. Perhaps he had more time to write, whereas I was committed to a program of pulling the library a little further into the later 1900s in a period when, to say the least, the then heavy hand of the Public Service Board was not always on my side!

What I gained, personally, from the NSW Working Party was an acquaintance with real historians, whose friendship and cooperation in general were to stand me in good stead. Who were these people? In no particular order, I see these 
names: J. M. Bennett; Ken Cable; Frank Crowley; Chris Cunneen; Rae (Justice) Else-Mitchell (later president of the Library Council of New South Wales, and a good if formidable friend to a new State librarian); Frank Farrell; Brian Fletcher; Hazel King; Beverley Kingston; W. G. Minn; Bruce Mansfield; Bruce Mitchell; Heather Radi; John Ryan; Gerry Walsh; John Manning Ward (later vicechancellor of the University of Sydney); Baiba Irving (later Mitchell librarian); Barry Andrews.

There was remarkably little change in the membership of the working party from 1973 until my retirement in 1987. My two immediate successors as State librarian, Alison Crook and Dagmar Schmidmaier, also chaired the working party. I believe that if the NSW Working Party gains something from the State library, it is equally true that the library gains, too; it is a good deal more, on both sides, than just tea and biscuits.

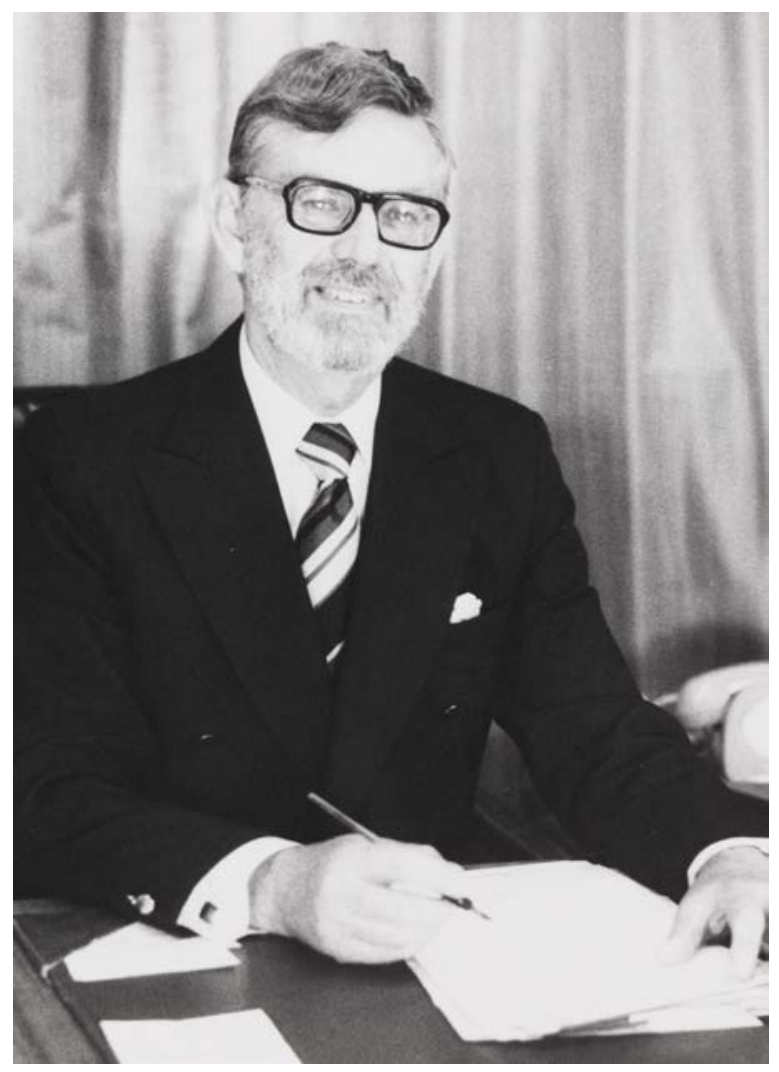

\section{Russell Doust, n.d.}

State Library of New South Wales

Russell Doust was the NSW State librarian and chair of the NSW Working Party from 1973 until 1987. 